\title{
Opportunities and challenges for statistics education in South Africa
}

\author{
Authors: \\ Temesgen Zewotir ${ }^{1}$ \\ Delia North \\ Affiliations: \\ ${ }^{1}$ School of Statistics and \\ Actuarial Science, University \\ of KwaZulu-Natal, \\ South Africa \\ Correspondence to: \\ Delia North \\ Email: \\ northd@ukzn.ac.za \\ Postal address: \\ Private Bag X54001, Durban \\ 4000, South Africa \\ Dates: \\ Received: 03 Apr. 2011 \\ Accepted: 01 Nov. 2011 \\ Published: 28 Nov. 2011 \\ How to cite this article: \\ Zewotir, T., \& North, D. \\ (2011). Opportunities and \\ challenges for statistics \\ education in South Africa. \\ Pythagoras, 32(2), Art. \\ \#28, 5 pages. http://dx.doi. \\ org/10.4102/pythagoras. \\ v32i2.28
}

The South African educational system is in a state of transformation as the Government embarks on a process of grappling with legacies of the past, whilst balancing risks and opportunities for the future. Accordingly, a new school curriculum with outcomes-based education as the fundamental building block was introduced along a sliding scale, starting in 1997. This curriculum, with a vast statistics content, has the potential to change the face of statistics education in South Africa, as statistics had previously been virtually absent from the school syllabus. This article highlights the challenges to and opportunities for optimising the teaching of statistics across all education levels in South Africa.

\section{Introduction}

In this information-driven society it is vital that all citizens are able to orient themselves in a world where evidence-based decision making is likely to call for data collection, organisational, analytical, interpretation and communication skills. Accordingly, statistics education is facing a critical global challenge to meet with an ever-increasing need to disseminate more data, accurately, in shorter times and in forms desired by users for further analysis (Wallman, 1993). In South Africa the training of statisticians and raising of levels of statistical literacy have to be planned carefully to make the most effective use of the limited training resources available. This article assesses the challenges and opportunities for statistics education in South Africa.

\section{Statistics education at school level}

It has been well documented that statistical concepts should be introduced into the school curriculum (e.g. Franklin et al., 2005; Gal, 2002; Wild \& Pfannkuch, 1999). This has resulted in mathematics curricula for primary and secondary schools being reformed to include statistics (North \& Scheiber, 2011).

Accordingly, in 1995 the Minister of Education announced the introduction of a new curriculum with outcomes-based education (OBE) as the fundamental building block (Botha, 2002; Department of Education, 1997). This curriculum was intended to catapult South Africa into the 21st century (Chisholm et al., 2000).

This curriculum was launched in March 1997 and became known as Curriculum 2005 ( Department of Education, 1997). Implementation of Curriculum 2005 was along a sliding scale, starting with Grade 1 in 1998. This curriculum was subsequently revised in 2002 and renamed the Revised National Curriculum Statement for Grades R-9, and implemented along a sliding scale starting in 2004 .

The National Curriculum Statement (NCS) was subsequently defined for Grades 10-12 (Department of Education, 2002, 2003) and was implemented for Grade 10 in 2006, Grade 11 in 2007 and Grade 12 in 2008. The first year that the Grade 12 students had received the full benefit of the new curriculum and wrote the first National Senior Certificate school-leaving examination based on the new NCS was thus 2008.

In the new curriculum emphasis is specifically placed on shifting from the traditional aims and objectives approach to OBE. This paradigm shift is seen as a prerequisite for achievement of the vision of an internationally competitive country. Outcomes-based curriculum development starts with the formulation of the purposes of learning, which are then used as the criteria for further curriculum development and assessment. One of the specific outcomes identified in the school mathematics curriculum is the use of data from various contexts to make informed judgements (Steffens \& Fletcher, 1999; North \& Zewotir, 2006a). This serves the ever-increasing need to understand data and to translate them into usable knowledge in the technological age of rapid information expansion. Recognition of the cross-curricular need for statistics as an 
anticipated outcome resulted in the assessment criteria of the NCS, including the collection of data (using methods such as interviews and sampling), application of statistical tools and communication and critical evaluation of findings.

The new OBE system requires that each learner either does Mathematics or Mathematical Literacy in each school year - a major shift from what had been the case prior to adoption of the new curriculum. It was previously possible to complete schooling without doing any form of mathematics in the last three grades of the schooling system. To get a grasp of the scale of the change, one needs to examine the number of school leavers with some form of mathematics in 2007 (when the old system was in place) compared to 2008 (first graduation year of learners under the NCS). A huge 'wave' came through in 2008, when a total of 592017 students registered for the final school examination in Mathematics or Mathematical Literacy, compared to a total of 347570 in the previous year (Appel, 2008).

Statistics (Data Handling) forms an integral new part of the Mathematics syllabus and is also present in the Mathematical Literacy syllabus of the NCS, adding to the dilemma of training many in-service mathematics teachers who have generally had little or no training in statistics. The dilemma is thus two-fold - training more mathematics teachers, and ensuring that existing teachers can cope with the vast new statistics content of the NCS (North \& Scheiber, 2008).

The statistics component of the NCS was initially developed by the Department of Education without any input from the South African Statistical Association (SASA), the mouthpiece of the majority of professional and practicing statisticians in South Africa. Training in statistics for mathematics teachers for the NCS was carried out by Department of Education subject advisors, themselves products of the previous curriculum and thus also not having the required statistics knowledge (North \& Scheiber, 2008). This prompted intervention from SASA to ensure that the potential successful introduction of Statistics, as specified in the NCS, was achieved.

SASA is accordingly actively involved in the teaching of statistics in schools via its Education Committee, a subcommittee with the specific brief of furthering statistics education at tertiary and preparatory (school) level. In 1998 contact was made with the Association for Mathematics Education of South Africa (AMESA), the association to which school mathematics teachers belong, with a view to closer collaboration with the intention of including school teachers in some of the initiatives of the Sixth International Conference on Teaching Statistics (North \& Zewotir, 2006a). This occasion marked the beginning of a closer bond between SASA and AMESA and has resulted in SASA members taking an active part in subsequent congresses and meetings of AMESA, as well as contributing to the AMESA newsletter.

The SASA Education Committee initiated an awareness of the dilemma of statistics education of school teachers by giving various talks at local conferences, holding workshops and helping with teacher training. However, it was only when Statistics South Africa (Stats SA), the national statistics office, launched the Maths4stats campaign (Stats SA, n.d.) that the human capacity and finances were available to address the dilemma on a national basis. The Maths4stats project addresses the dilemma by aiming to provide a rollout plan for statistics training for roughly 10000 mathematics teachers (Grades 10-12) from 28000 schools. The objective of the Maths4stats campaign was to create a specialised body of teachers with a passion for mathematics, and to instil a love for and interest in mathematics and statistics in teachers and learners. Details of the project can be found in North and Scheiber (2008) and Stats SA (n.d.). The long-term aim of this project is to strengthen expertise in Statistics at all levels so that ordinary people have trust in the information they receive from Stats SA (Lehohla, 2002).

Through a focus on in-service teachers, the scope of statistics education is being broadened considerably at school level. The issue of statistics training of pre-service teachers is addressed by universities and teacher training centres, as they are starting to incorporate statistics education courses into their formal teacher training courses (Wessels, 2008). Teachers are thus being prepared to teach statistics by enabling pre-service teachers to develop the statistical literacy, thinking and reasoning abilities called for in the NCS. There is a need for teachers to have the knowledge to teach the elements that are essential for basic statistical thinking, that is, an appreciation of uncertainty and data variability and their impact on decision making (Sylwester, 1993). This is an attempt to make precise and explicit what the data have to say about the problem of interest (Mallows, 1998). By providing exposure to and instruction in this type of thinking, we can hasten development of the way of approaching problems and methodology for problem solving which will be called on in later years (Chance, 2002).

\section{Statistics and statistics education at university level}

Statistics syllabi were introduced at South African universities in the 1930s and had a theoretical focus, deliberately shying away from Applied Statistics (Steffens, 1998). Statistics historically started at second-year level (in a three-year programme leading to a Bachelor's degree in Statistics), as one needed a high level of mathematics in order to follow the calculus-based approach to teaching statistics. Historically, South African universities thus produced statisticians that were not ideally suited to any occupation other than in academia, since the statistics training was geared towards furthering the discipline in a theoretical way (De Wet, 1998). It must, however, be noted that a few individuals did manage to excel in the application of statistics through their own self-interest rather than through skills acquired from their tertiary-level statistics training. For instance, Dr Herbert Sischel (1915-1995), a world-renowned statistician from the University of the Witwatersrand, made great advances in both theoretical and applied statistics. 
In recent times a more balanced view of theory and applications has become apparent in statistics training at South African universities (De Wet, 1998; Steffens, 1998). Currently statistics departments typically offer a three-year programme leading to a Bachelor's degree in Statistics, a one-year Honours degree, one- or two-year Masters programmes and four-year $\mathrm{PhD}$ programmes. Masters and PhD programmes are mainly by research dissertation only.

The current structure of the statistics courses in the various South African universities is very similar. Two courses (one per semester) at first-year level, two courses at secondyear level and four courses at third-year level are generally required for the BSc programme. The two courses (one per semester) in the first year offer an introductory approach to the theory, principles and applications of statistics. The two courses in second year mainly deal with distribution theories, estimation procedures and inference. The third-year courses are a mix of methods and applications with a theoretical basis. Relatively intermediate-level advanced statistical theories and methods with computer practicals are offered at honours level. A common feature of honours programmes amongst South African universities is the statistics project. ${ }^{1}$

Mathematics teaching at school level in South Africa lags behind many other countries (Reddy, 2006), so that the majority of the first-year students have a poor or insufficient mathematical foundation and cannot cope with the theoretically oriented first-year courses such as Statistics (Frick, 2008). To alleviate this problem, a number of universities have introduced special tutorials and hot seats (private lessons by postgraduate students) in first-year Statistics courses. The use of local instead of foreign textbooks can, to a certain extent, bridge the problem of presenting examples that the students do not relate to and consequently cannot put into context (Steffens, 1998).

At least one module in a statistics service course is an essential part of almost all programmes at South African universities. One of the objectives of such a course is to equip students with the basic statistical methods for their everyday life, that is, a holistic approach to produce well-rounded graduates. In most cases such an introductory statistics course is offered at first-year level and usually has little or no prerequisites, beyond some mathematics requirement at high school level. The course tends to dwell more on theory and less on applications of statistics, thus fostering an inwardly focused approach where theory plays the dominant role, followed by a few techniques with the hope that the value of the subject will speak for itself.

\footnotetext{
1.As a typical example, refer to these university School of Statistics websites: UKZN: http://statsactsci.ukzn.ac.za/Faculty_Handbook/Statistics_Undergraduate aspx WKZN: http://statsactsci.ukzn.ac.za/Faculty_Handbook/Statistics_Undergraduate aspx Wits: http://www.wits.ac.za/academic/science/stats/cour UCT: http://web.uct.ac.za/depts/stats/

Stellenbosch: http://academic.sun.ac.za/statistics/
}

It is argued here that the underlying purpose is implicit rather than explicit, that is, the student graduates from the module with a grasp of some theoretical aspects of statistics but will generally have very little understanding as to how to apply the theory learnt in practice (McLean, 2000). This expectation is far from reality, as many students find statistics courses difficult, with a resulting poor pass rate in such courses (North \& Zewotir, 2006b). For instance, the average pass rate for third-year engineering students in a statistics service course offered at the University of KwaZulu-Natal for the period 1997-2005 was 73.8\%, whilst the average pass rate for third-year engineering courses over this period was $86 \%$ (Zewotir \& North, 2007).

To get a handle on the number of students in the various statistics modules around the country, refer to Table 1.

Due to the sheer shortage of statisticians in the country, BSc and Honours graduates in Statistics receive lucrative offers from industry, business and government. Accordingly, very few South African statistics graduates opt to pursue postgraduate studies in Statistics or Statistics Education (Wessels, 2008). Currently there are not enough statisticians being produced to meet the demand of personnel with at least an MSc degree in Statistics. The International Review Panel Report, the Review of Mathematical Sciences Research at South African Higher Education Institutions, concludes that 'the shortage of academic statisticians is so critical that the field is in danger of disappearing through lack of academic capacity', further noting that 'the closure of academic departments is a real possibility' (Department of Science and Technology, 2008, p. 3). Diab and Gevers (2009, p. 78) come to the same conclusion:

\begin{abstract}
... there is acute shortage of qualified statisticians with no senior established academic in some of the statistics departments at universities in South Africa. There is danger of the imminent collapse of research activity in statistics when the present cohort of senior researchers retire.
\end{abstract}

\section{Professional association}

SASA was founded in 1953 and held its first conference in 1958. The Association facilitates the advancement of statistical knowledge by creating a forum for collaboration between academic and practicing statisticians in order to nurture and build capacity of statisticians in South Africa. Accordingly, the association organises an annual conference, has two publications and runs a website. The two publications are the SASA Newsletter and the South African Statistical Journal. These two publications are mailed to members and are placed in libraries of all tertiary institutions in South Africa. As can be seen from Table 2, the number of SASA members has steadily increased over the last three years. The total number of SASA members was 430 in 2010, an increase

TABLE 1: Number of students in Statistics programmes at South African universities, 2006.

\begin{tabular}{lcccccc}
\hline Description & \multicolumn{3}{c}{ BSc programme } & Honours & MSc & Service courses \\
\cline { 2 - 5 } & 1st year & 2nd year & 3rd year & & & \\
\hline Number of students & 4274 & 1229 & 969 & 203 & 25 & 90 \\
\hline
\end{tabular}

Source: South African Statistical Association. (2006, September). SASA News, p. 19 
TABLE 2: Number of SASA members by race and gender in 2007 and 2010.

\begin{tabular}{|c|c|c|c|c|c|c|c|c|c|c|c|c|}
\hline \multirow[t]{2}{*}{ Members } & \multicolumn{3}{|c|}{ Black } & \multicolumn{3}{|c|}{ White } & \multicolumn{3}{|c|}{ Asian (Indian) } & \multicolumn{3}{|c|}{ Total } \\
\hline & 2007 & 2010 & $\%$ increase & 2007 & 2010 & $\%$ increase & 2007 & 2010 & $\%$ increase & 2007 & 2010 & $\%$ increase \\
\hline Male & 33 & 78 & 136 & 142 & 164 & 15.5 & 4 & 6 & 50.0 & 179 & 248 & 38.5 \\
\hline Female & 13 & 51 & 292 & 103 & 119 & 15.5 & 7 & 12 & 71.4 & 123 & 182 & 50.4 \\
\hline Total & 46 & 129 & 180 & 245 & 283 & 16.3 & 11 & 18 & 63.3 & 302 & 430 & 42.4 \\
\hline
\end{tabular}

Source: P.J. Mostert, SASA Treasurer (personal communication, June 20, 2011)

of $42 \%$ from the membership of 302 in 2007. As a result of the divisions that existed pre-1994, the negligible number of black and Asian SASA members in the past has recently started to grow rapidly. In 2007 about 15\% of SASA members were Black; only three years later, in 2010, this figure had doubled to $30 \%$. Interestingly, the number of female Black SASA members increased from 4\% (13 out of 302) in 2007 to $12 \%$ (51 out of 430 ) in 2010, indicating that the membership of the association is normalising.

\section{Conclusion}

Statistical thinking, which calls for evidence of critical, investigative, creative, problem-solving and communicative skills, will prove to be difficult in the OBE set-up. When students engage with a mathematics course, they are generally accustomed to calculating one definitive correct answer that can be underlined as 'the correct answer', whilst in the statistics class there may be many different answers that could all be considered to be correct, and the emphasis would be on the interpretation of that answer. For example, whether to use the mean, median or mode when determining the measure of central tendency of the data could potentially give different results, but there is not one 'correct' answer. One needs to know what the strength of each measure is and which is best to use under which circumstances. This calls for a whole new mindset - one where the habits of questioning, justifying and writing in one's own words require specific instruction in the introductory statistics course, calling for teachers that have confidence and expertise in this area. Teachers thus need to be aware of the need to allow and even reward alternative ways of examining and interpreting data.

What is evident from the experiences of other statistics educators around the world is that many teachers do not consider themselves well prepared to teach statistics, nor to address their students' difficulties (Batanero, Burrill \& Chris, 2011). The joint study by the International Commission on Mathematical Instruction and the International Association for Statistics Education aimed to address this omission by promoting research specifically focused on the education and professional development of teachers to teach statistics (Batanero, Burrill, Reading \& Rossman, 2008). The research of this study suggests that in order to teach statistics effectively, teachers must understand the nature of statistics and its role in all aspects of today's information-driven society (Batanero et al., 2011).

Preparing teachers to teach statistics is vital to further the improvement of statistics education at all levels, and in all contexts. It is thus in the interest of all South African roleplayers to work collaboratively in order to promote statistics education at grassroots level. The first steps taken by Stats SA and the SASA to jointly improve the statistics-proficiency level of in-service teachers is gaining momentum and making great strides (North \& Scheiber, 2008).

On the other hand, efforts of statistics educators at higher education institutions to collaborate more effectively with experts in other fields to revise and develop statistics service courses is not yet satisfactory. It takes motivation and perseverance to make changes to any curriculum, and is often easier just to retain the status quo, that is, stick with the line of least resistance and carry on doing things the way they have always been done in the past. The result is that statistics service courses have often not evolved at the rate that they should have.

Another area of concern is that some disciplines offer statistics service courses within their own discipline code, that is statistics is taught by non-specialists. The lesson to be learnt from this is that unless the statistics departments offer service courses with relevance and ease, students will continue to have difficulty in passing, since many students experience anxiety when required to take a statistics course (North \& Zewotir, 2006a). This is particularly so since many such courses focus on statistical methods (computations) rather than on statistical reasoning (concepts and thinking). To reduce anxiety and provide the most optimal base for future development of statistics education at all levels, it is imperative that all school and introductory statistics modules should be designed in a way such that calculations are delayed until concepts have been mastered, with an emphasis on the use of real or realistic data. Preparing teachers to teach statistics meaningfully is thus a vital and important research area that has not received enough attention (Wessels, 2008).

The outcomes-based reforms that took place in South Africa had much in common with curriculum reforms that previously took place in the United Kingdom, New Zealand, Australia, Canada and the United States of America (Aldridge, Fraser \& Laugksch, 2011). The teaching of statistics reflects, in unexpected ways, the historical, economic and political circumstances of the country, and of course these differences are reflected in the training programmes (Loynes, 1987). What is a common thread in many countries, however, is the inclusion of statistics into school syllabi and the desire to improve statistics education at all levels, from elementary (primary) school through to the training of professionals.

It is thus argued that no matter how big the challenges to successfully introducing statistics at school level in South Africa, this has the potential to improve basic statistical literacy of school leavers. More importantly, it will increase 
the awareness of statistics as a study area of choice amongst students entering universities and teacher training centres, thus creating an opportunity for statistics education to grow at all levels in South Africa.

\section{Acknowledgements}

We are grateful to the SASA Treasurer, Prof. P.J. Mostert, for providing data on the number of SASA members.

\section{Competing interests}

We declare that we have no financial or personal relationship(s) which may have inappropriately influenced us in writing this article.

\section{Authors' contributions}

T.Z. performed the analysis of data and drafted the manuscript. D.N. made contributions to collecting relevant data and editing the manuscript. Both T.Z. and D.N. contributed to the conception and design of the study, and both wrote and edited the final version of the manuscript.

\section{References}

Aldridge, J.M., Fraser, B.R., \& Laugksch, R. (2011). Relationships between the schoollevel and classroom-level environment in secondary schools in South Africa. South African Journal of Education, 31, 127-144. Available from http://www. sajournalofeducation.co.za/index.php/saje/article/view/407/230

Appel, M. (2008). Mathematical literacy pass rate encouraging for SA. Available from http://www.ecdoe.gov.za/news article/48/Mathematical-literacy-pass-rateencouraging-for-SA.

Batanero, C., Burrill, G., \& Chris, R. (2011). Teaching statistics in school mathematics: Challenges for teaching and teacher education: A Joint ICMI/IASE Study: The 18th ICMI Study. New York, NY: Springer. http://dx.doi.org/10.1007/978-94-007-11310

Batanero, C., Burrill, G., Reading, G., \& Rossman, A. (Eds.). (2008). Joint ICMI/IASE study: Teaching statistics in school mathematics - Challenges for teaching study: Teaching and teacher education. Proceedings of the ICMI Study 18 Conference and IASE errey, Mexico: International Statistical Institute and International Commission on Mathematical Instruction. Available from http://www.stat.auckland.ac.nz/ iase/publications. php?show=rt08

Botha, R.J. (2002). Outcomes-based education and educational reform in South Africa. International Journal of Leadership in Education: Theory and Practice, 5 , 361-371. http://dx.doi.org/10.1080/13603120110118831

Chance, B.L. (2002). Components of statistical thinking and implications for instruction and assessment. Journal of Statistics Education [Online], 10(3). Available from www.amstat.org/publications/jse/v10n3/chance.html

Chisholm, L., Volmink, J., Ndhlovu, T., Potenza, E., Mahomed, H., Muller, J., et al. (2000). A South African curriculum for the twenty-first century: Report of the review committee on Curriculum 2005. Pretoria: Ministry of Education.

Department of Education. (1997). Senior phase policy document. Pretoria: Department of Education.

Department of Education. (2002). Revised national curriculum statement: Grades $R-9$ (Schools): Mathematics. Pretoria: Department of Education.

Department of Education. (2003). National curriculum statement: Grades 10-12 (General): Mathematics. Pretoria: Department of Education.

Department of Science and Technology. (2008). Review of mathematical sciences research in South Africa higher education institutions: International review panel report. Available from http://www.nrf.ac.za/files/file/Report.pdf

De Wet, J.I. (1998). Teaching of statistics to historically disadvantaged students: The South African experience. In Proceedings of the Fifth International Conference on the Teaching of Statistics, 21-26 June 1998, Vol. 2 (pp. 573-577). Singapore: Nanyang Technological University. Available from http://www.stat.auckland. ac.nz/ iase/publications/2/Topic5e.pdf
Diab, R., \& Gevers, W. (Eds.) (2009). The state of science in South Africa. Pretoria: Academy of Science of South Africa. Available from http://www.assaf.co.za/ePub/ ASSAf/ASSAfTWAS.htm

Franklin, C., Kader, G., Mewborn, D.S., Moreno, J., Peck, R., Perry, M., et al. (2005). Guidelines for assessment and instruction in statistics education (GAISE) report: A pre-K-12 curriculum framework. Georgia: American Statistical Association. Available from http://www.amstat.org/education/gaise/GAISEPreK-12_Full.pdf

Frick, B.L. (2008). The profile of the Stellenbosch University first year students: Present and future trends. Preliminary research report. Draft 4. Available from http://stbweb02.stb.sun.ac.za/sol/documents/Student\%20profile\%20report\%20 draft\%204.pdf

Gal, I. (2002). Adult's statistical literacy. Meanings, components, responsibilities International Statistical Review, 70(1), 1-25. http://dx.doi.org/10.2307/1403713, http://dx.doi.org/10.1111/j.1751-5823.2002.tb00336.x

Lehohla, P. (2002). Promoting statistical literacy: A South African prespective. In B. Phillips (Ed.), Proceedings of the Sixth International Conference on Teaching of Statistics $[C D]$. Voorburg, The Netherlands: International Statistical Institute. Available from http://www.stat.auckland.ac.nz/ iase/publications/1/5d1_leho. pdf

Loynes, R.M. (Ed.). (1987). The training of statisticians round the world. Voorburg, The Netherlands: International Statistical Institute. Available from http://www.stat. auckland.ac.nz/ iase/publications/train1987/

Mallows, C. (1998). The Zeroth problem. The American Statistician, 52, 1-9. http:// dx.doi.org/10.2307/2685557

McLean, A. (2000). The predictive approach to statistics. Journal of Statistics Education, 8(3) [Online]. Available from http://www.amstat.org/publications/jse/ secure/v8n3/mclean.cfm

North, D., \& Scheiber, J. (2008). Introducing statistics at school level in South Africa: The crucial role played by the national statistics office in training in-service teachers. In C. Batanero, G. Burrill, C. Reading, \& A. Rossman (Eds.), Proceedings of the 18th ICMI Study Conference and 2008 IASE Round Table Conference, 30 June - 04 July 2008. Voorburg, The Netherlands: International Statistical Institute and International Commission on Mathematical Instruction. Available from http://www.ugr.es/ icmi/iase_study/Files/Topic6/T6P2_North.pdf

North, D., \& Scheiber, J. (2011). The role of statistical offices and associations in supporting the teaching of statistics at school level. In C. Batanero, G. Burrill, C. Reading, \& A. Rossman (Eds.), Teaching statistics in school mathematics: Challenges for teaching and teacher education: A Joint ICMI/IASE Study: The 18th Challenges for teaching and teacher education: A Joint ICMI/IASE Study: The 18th 94-007-1131-0_37

North, D., \& Zewotir, T. (2006a). Introducing statistics at school level in South Africa. In A. Rossman, \& B. Chance (Eds.), Proceedings of the Seventh International Conference on Teaching Statistics, 02-07 July 2006. Salvador, Brazil: International Association for Statistical Education. Available from http://www.stat.auckland. ac.nz/ iase/publications/17/2F1_NORT.pdf

North, D., \& Zewotir, T. (2006b). Teaching statistics to social science students: Making it valuable. South African Journal of Higher Education, 20(4), 503-514.

Reddy, V. (2006). Mathematics and science achievement at South African schools in TIMSS 2003. Cape Town: Human Sciences Research Council Press. Available from http://www.hsrcpress.ac.za/product. php? productid $=2148$

South African Statistical Association. (2006, September). SASA News, p. 19. ISSN 1011 8039.

Statistics South Africa. (n.d.). Maths4stats: Towards a nation that counts. Available from http://www.statssa.gov.za/maths4stats/

Steffens, F.E. (1998). Statistical education in the African region: Private experiences in South Africa and Namibia. In Proceedings of the Fifth International Conference in South Africa and Namibia. In Proceedings of the Fifth (nternational Conference on the Teaching of Statistics, 21-26 June 1998, Vol. 2 (pp. 572-578). Singapore:
Nanyang Technological University. Available from http://www.stat.auckland. ac.nz/ iase/publications/2/Topic5d.pdf

Steffens, F.E., \& Fletcher, L. (1999). Statistics as part of the mathematics curriculum in South Africa. In Proceedings of the First International Conference of the Mathematics Education into the 21st Century Project, Vol. 1 (pp. 298-305). Available from http://math.unipa.it/ grim/ESteffensFletcher298-305.PDF.

Sylwester, D. (1993. February). Statistical thinking. American Statistical Association Newsletter. p. 2-3.

Wallman, K.K. (1993). Enhancing statistical literacy: Enriching our society. Journal of the American Statistical Association, 88, 1-8. http://dx.doi.org/10.2307/2290686

Wessels, H.M. (2008). Statistics in the South African school curriculum: Content, assessment and teacher training. In C. Batanero, G. Burrill, C. Reading, \& A Rossman (Eds.), Proceedings of the 18th ICMI Study Conference and 2008 IASE Round Table Conference, 30 June - 04 July 2008 . Voorburg The Netherlands: Round Table Conference, 30 June - 04 July 2008. Voorburg, The Netherlands: International Statistical Institute and International Commission on Mathematical
Instruction. Available from http://www.ugr.es/ icmi/iase study/Files/Topic1/ Instruction. Available
T1P3_Wessels.pdf

Wild, C., \& Pfannkuch, M. (1999). Statistical thinking in empirical enquiry. Internationa Statistics Review, 67(3), 223-265. http://dx.doi.org/10.2307/1403699, http:// Statistics Review, 67(3), 223-265. http://dx.do
dx.doi.org/10.1111/j.1751-5823.1999.tb00442.x

Zewotir, T., \& North, D. (2007). Focus on the statistical education of prospective engineers in South Africa. Pythagoras, 65, 18-23. Available from http://www. pythagoras.org.za/index.php/pythagoras/article/view/87 